\title{
Translanguaging space and translanguaging practices in multilingual Russian-speaking families
} Sviatlana KARPAVA ${ }^{1}$, Natalia RINGBLOM ${ }^{2}$ and Anastassia ZABRODSKAJA ${ }^{3}$

\author{
${ }^{1}$ University of Cyprus \\ Nicosia, Cyprus \\ ${ }^{2}$ Stockholm University \\ Stockholm, Sweden \\ Dalarna University \\ Falun, Sweden \\ ${ }^{3}$ Tallinn University \\ Tallinn, Estonia
}

\begin{abstract}
Translanguaging is seen both as a threat and as an opportunity for minority language development and transmission. While the theme of translanguaging has been explored especially in a context of migration, the novelty of this study lies in its investigation of the multiple contexts in which translanguaging is examined. In order to understand the nature of translanguaging, we adopt a novel interdisciplinary approach and view it in all its complexity, including liminal spaces of linguistic landscape. Family language policy affects the home linguistic environment. Our purpose is to investigate language choices by multilingual Russian-speakers in Cyprus, Sweden and Estonia, immigrant and minority settings, and try to understand how they are reflected in the multilingual interaction of the families. Using ethnographic participant observations and oral spontaneous multilingual production, our study attempts to describe how communication is managed through translanguaging practices among multilingual Russian-speaking families' members in the cultural and linguistic environments of the three countries. By looking closely at the complexities of translanguaging space, it is our ambition to gain new insights about how it is organised and how translanguaging becomes a valuable linguistic resource in multilingual families. Our results indicate that translanguaging practices can be used in family conversational contexts and contribute to the creation of a rich and positive family repertoire. A new norm of Russian has been developed in all the three settings. A language shift can happen more quickly than expected, and, thus, it is important for parents to provide many opportunities for practising Russian as the L1.
\end{abstract}

Keywords: translanguaging, language transmission, multilingualism, minority language, Russian

\section{For citation:}

Karpava, Sviatlana, Natalia Ringblom \& Anastassia Zabrodskaja. 2021. Translanguaging space and translanguaging practices in multilingual Russian-speaking families. Russian Journal of Linguistics 25 (4). 931-957. https://doi.org/10.22363/2687-0088-2021-25-4-931-957 


\title{
Пространство транслингвизма и транслингвальные практики в многоязычных русских семьях
}

\author{
Светлана КАРПОВА ${ }^{1}$, Наталия РИНГБЛОМ ${ }^{2}$, Анастасия ЗАБРОДСКАЯ ${ }^{3}$ \\ ${ }^{1}$ Университет Кипра \\ Никосия, Кипр \\ ${ }^{2}$ Стокгольмский университет \\ Стокгольм, Швеиия \\ Университет Даларны \\ Фалун, Швеиия \\ ${ }^{3}$ Таллинский университет \\ Таллин, Эстония
}

\begin{abstract}
Аннотация
Транслингвизм можно рассматривать и как угрозу, и как возможность для развития и передачи языков меньшинств из поколения в поколение. Несмотря на то, что тема транслингвизма достаточно исследована, особенно в контексте миграции, новизна этой статьи заключается в том, что в ней рассматриваются множественные контексты, связанные с проблемой транслингвизма. Чтобы понять природу данного явления, мы применяем инновационный междисциплинарный подход и исследуем транслингвизм во всей его сложности, включая лиминальные пространства языкового ландшафта. Политика в области семейного языка влияет на домашнюю языковую среду. Наша цель - изучить выбор языков многоязычными русскоговорящими иммигрантами и представителями меньшинств на Кипре, в Швеции и в Эстонии и попытаться понять, как они отражаются в многоязычном семейном дискурсе. Используя этнографические наблюдения за участниками и устное спонтанное многоязычное речепроизводство, мы пытаемся описать, как коммуникация между членами многоязычных русскоязычных семей в культурной и языковой среде трех стран осуществляется посредством практики транслингвизма. Детально исследуя сложности транслингвального пространства, мы стремимся по-новому взглянуть на то, как оно организовано и как транслингвизм становится ценным лингвистическим ресурсом в многоязычных семьях. Полученные результаты показывают, что транслингвизм может использоваться в семейном контексте и способствовать насыщенному и позитивному семейному общению. В условиях всех трех стран происходит становление новой нормы русского языка. Смена языка может произойти быстрее, чем ожидалось, и поэтому для родителей важно предоставить детям возможности практиковать русский язык в качестве первого.
\end{abstract}

Ключевые слова: транслингвизм, межпоколенческая передача языка, многоязычие, язык меньшинства, русский язык

\section{Для цитирования:}

Karpava S., Ringblom N., Zabrodskaja A. Translanguaging space and translanguaging practices in multilingual Russian-speaking families. Russian Journal of Linguistics. 2021. Vol. 25. № 4. P. 931-957. https://doi.org/10.22363/2687-0088-2021-25-4-931-957

\section{Introduction}

Applying the theories of family language policy (King et al. 2008) (hereafter FLP), we explored divergent language choices within the family context, minority and immigrant contexts of northern and southern Europe, in connection with 
available linguistic resources. FLP reflects language ideology, language policies in the society (Lane 2010, Curdt-Christiansen 2014a), the immigrant experience of parents (Curdt-Christiansen 2009), their beliefs (King \& Fogle 2006) and parental "impact beliefs" (Pérez Báez 2013). Previous research on state language policy (Lane 2010, Curdt-Christiansen 2014b) has shown that macro factors affect parental beliefs at the micro level, i. e. "impact beliefs" (Curdt-Christiansen 2009, Pérez Báez 2013). Weak impact beliefs can lead to the inability to prevent language shift and a lack of success regarding FLP, while high expectations of parents regarding their children's future education and career opportunities with relation to multilingualism lead to successful FLP and the raising of bilingual/multilingual children.

By translanguaging we mean that a bilingual person has one integrated linguistic system (García 2009) as a result of flexible bilingualism and multiple discursive practices. According to Li Wei (2011), translanguaging space is created by and for translanguaging. In our previous study, we explored the way parents and children in multilingual families communicate on a family level, demonstrating how family language policy and translanguaging can support and enhance dynamic multilingualism in the family and integrate Russian as a minority language in a societal and educational context (Karpava et al. 2019).

In this paper, we suggest that looking closely at the complexities of translanguaging space might enable FLP researchers to develop new ideas about how the inclusion of all available linguistic resources into the ongoing social practice of interacting works and, more generally, how translanguaging space is organised. Multilingual interaction and translanguaging promote the strategic use of language and the agency of speakers (Garcia \& Li Wei 2014). Translanguaging becomes a valuable resource and an ideological practice, especially in immigrant and minority contexts (Garcia \& Leiva 2014), which is relevant to our study.

Translanguaging is a complex phenomenon that cannot be viewed in simple terms and from one perspective only, and should be studied in all of its complexity. In this paper, one of the purposes is to explore this complexity. Translanguaging practices can support and expand dynamic multilingualism and integrate a minority or an immigrant language into a wider context. However, from the language transmission perspective translanguaging can be highly controversial since it can increase language change when used in more and more domains, especially when families do not make conscious choices regarding specific language management and have "laissez-faire" attitudes regarding language choice. We suggest that two scenarios are possible here: either language change or a new variety of Russian that is developed in the three countries studied (Cypriot Russian, Estonian Russian and Swedish Russian). In this article, we focus on new varieties, and in our examples we reveal the involvement of all family members in this process and, in general, the results were positive.

This study aims to investigate multilingual interaction and translanguaging practices, affected by translanguaging spaces and linguistic landscapes as well as sociolinguistic situations, among Russian-speaking parents and their children in 
three different linguistic environments: Cyprus, Estonia and Sweden. Although these countries have different geographical location, these are closely related to Russia culturally, historically and/or economically: through past or recent intensive migration, membership in political and economic unions and strategic partnerships, and through stereotypes and the clichés of historical memory carrying both positive and negative traits. In all the three countries, there are substantial Russian-speaking communities which appeared there for different historical and political reasons: in Estonia this happened mainly through colonisation during the imperial period and Soviet era; post-revolutionary and post-Soviet emigration occurred in Sweden; and Cyprus has become both a Russian tourism Mecca and a magnet for (rich) migrants since the 1990s.

The data were collected using ethnographic participant observations. This helped to gain a deeper understanding of how translanguaging practices are managed in multilingual Russian-speaking families in three different environments and what differences and similarities could be observed between them.

\section{Theoretical framework for the present study: Translanguaging}

Uninhibited switching between languages, i. e. code-switching, is considered to be a norm. There are many different terms for code-switching: these include "loanword" (Haugen 1950) or "borrowing" (Poplack \& Sankoff 1984), "codemixing" (Appel \& Muysken 1987), "transversion" (Clyne 2003) and "convergence" (Gardner-Chloros 2009). Code-switching may cause language change (Thomason 2001). Heine \& Kuteva (2005) view code-switching as a synonym of borrowing. Matras (2009:114) distinguishes between situational switching and discourserelated switching. Gardner-Chloros (2010) refers to code-switching, language mixing and "fused lects" which can lead to language change.

García \& Li Wei (2014) proposed a translanguaging framework, according to which bilingualism and multilingualism are not marked language practices, but norms. The traditional view of bilingualism, with separate linguistic systems, is rejected as bilingual/multilingual speakers translanguage and choose various linguistic features depending on the context in creative and critical ways (Li Wei 2011).

Translanguaging is a systematic pedagogic, scaffolding strategy of using two or more languages in alternation that boost competence and performance in all of the languages (Lewis et al. 2012). Translanguaging can be used spontaneously or for pedagogical purposes (García 2009). The former refers to the "ability of multilingual speakers to shuttle between languages, treating the diverse languages that form their repertoire as an integrated system" (Canagarajah 2011: 401); the latter involves the scaffolding of comprehension in an educational setting, and is also called pedagogical translanguaging, intentional translanguaging or classroom translanguaging (Cenoz \& Gorter 2017).

Spontaneous translanguaging is an essential part of bilingual/multilingual social and language practice, it is not just code-switching or language mixing, and 
it presupposes code fluidity (García \& Li Wei 2014), depending on the situation (Canagarajah 2015). Previous research on spontaneous translanguaging focused on the use of English and an additional language, such as Spanish, Punjabi and Mandarin, in English-speaking countries (García 2009, Creese \& Blackledge 2010, Martinez-Roldán 2015, Gort \& Sembiante 2015), regional minority languages and educational contexts (Lewis et al. 2012, García \& Li Wei 2014, García et al. 2016, García \& Kleyn 2016).

Translanguaging allows bilinguals/multilinguals to create identities and to participate in multilingual discursive practice in meaningful ways (García 2009, Canagarajah 2011). Translanguaging is described as an effective strategic communication in which a speaker chooses necessary linguistic features from their linguistic repertoire (García \& Li Wei 2014). According to Makalela (2015: 16), translanguaging is "a fluid communicative language practice where the languages of input and output were purposefully juxtaposed." The focus of translanguaging is on the cognitive and linguistic skills of the interlocutors in bilingual/multilingual discourse. García \& Kleyn (2016: 14) proposed that "translanguaging refers to the deployment of a speaker's full linguistic repertoire, which does not in any way correspond to the socially and politically defined boundaries of named languages."

\subsection{Translanguaging space}

Lefebvre (1991) suggested the idea of social or socially produced space. Jewitt (2016) views space as a semiotic resource. The term "spatial repertories" was proposed by Pennycook and Otsuji (2014:161). Li Wei (2011) proposed the term "translanguaging space," which includes translanguaging practices, multilingual, multimodal and multisensory communication, and meaning co-production: language, cognitive and semiotic systems, attitudes, identities and ideologies are involved (García \& Li Wei 2014, Hua et al. 2017). Translanguaging space presupposes that signs and resources are interconnected for space production. As suggested by Li Wei (2011), translanguaging space, i. e. socially constructed contexts, allows individuals to use their linguistic resources for communication in a strategic way. Translanguaging "transgresses and destabilizes language hierarchies, and at the same time expands and extends practices that are typically valued in school and in the everyday world of communities and homes" (García \& Li Wei 2014: 68).

Translanguaging space is a space created by and for translanguaging practices, a space where multilingual individuals integrate social spaces (and thus "language codes") that were formerly practised separately in different spaces by "bringing together different dimensions of their personal history, experience and environment, their attitude, belief and ideology, their cognitive and physical capacity into one coordinated and meaningful performance" (Li Wei 2011: 1223). It presupposes "multimodalities - gestures, objects, visual cues, touch, tone, sounds and other modes of communication besides words - and online and digital media 
afford new translanguaging spaces and resources for multilingual and multimodal communication" (Hua et al. 2015: 10).

Within the socio-cultural perspective, languaging is a social act in the process of meaning construction that has a fluid, dynamic nature (García 2009). Languages are seen as semiotic resources and not discrete systems (Hua et al. 2015); "there are no clear-cut boundaries between the languages of bilinguals...," rather there is "a languaging continuum that is accessed" (García 2009: 47). Each language has its functions associated with certain power, prestige and identity.

\subsection{Translanguaging, FLP and minority/immigrant languages}

Minority and immigrant languages are vulnerable. Hélot \& De Mejía (2008) have found that whether bilingualism is accepted or not depends on the status of the language, whether it is prestigious or not; minority languages are usually nonprestigious and are often associated with low socio-economic status, shame and backwardness (Cenoz \& Gorter 2017). As we showed earlier, the same language (Russian in our case) can be more accepted in one setting/context and less accepted in another (Karpava et al. 2020).

Translanguaging can increase the comprehension of minority languages (see studies by Lowman et al. 2007: Māori vs. English, Lewis et al. 2012: Welsh vs. English, Llurda et al. 2013: Catalan vs. English). The development of languages is affected by socio-economic and socio-political factors. Translanguaging space allows the act of translanguaging and creates the opportunity for flexible and dynamic multilingual language use and the enhancement of cultural identities (Canagarajah 2011). According to Otheguy et al. (2015: 283), translanguaging can have a positive effect on minority languages. Sustainable translanguaging is associated with balance, language awareness and metalinguistic awareness (Cenoz \& Gorter 2017). Balancing between different languages involves a process of constant negotiation and here the role of Russian-speaking parents is especially important. Translanguaging is jointly produced, and if co-conversationalists start producing phrases and sentences relying more and more on majority language resources, without using Russian words and structures, then a language shift occurs in the speech of younger family members.

García (2009), Cenoz \& Gorter $(2011,2015)$ and García \& Li (2014) have suggested the idea of an integrated linguistic repertoire. Otheguy et al. (2015) have emphasised the importance of the legitimisation of translanguaging practices in order to protect minority languages. Research on translanguaging and translingual practices has shown that new multilingual ideologies are being developed (May 2014, Cenoz \& Gorter 2015). Li Wei (2018) states that translanguaging can empower speakers and can provide them with opportunities for the legitimate use of various languages (Cenoz \& Gorter 2019).

Language ideologies, social functions, political power and economic values, as well as views and beliefs about languages and language practices (CurdtChristiansen 2009, 2014b, 2016) affect language choice, use and maintenance. 
There may be both agreement and disagreement regarding FLP among the parents in one family that can affect language practice and management (King et al. 2008). Kirsh (2012) conducted research on Luxembourgish-English families in the UK and how ideology in the mainstream society restricts the possibility of raising bilingual children. A similar situation was observed by ÓhIfearnáin (2013) with Irish Gaaeltacht, and by Simpson (2013) in Australia.

There is a hierarchical order in the use of languages and this can lead to language maintenance, language shift or language loss. There is negotiation, mediation and evaluation of identities and sociocultural values, which can be accepted or rejected in bilingual/multilingual interaction (Curdt-Christiansen 2013, 2016).

Language policy is guided top down by governments and authorities and bottom up by parents (Wiley \& García 2016), so the agency of parents should be taken into consideration. A lot of families try to follow the "one person - one language" strategy, but sometimes some flexibility is needed. Their language practices can be quite complex and determine how they communicate: with parents, children, siblings, relatives and friends, on-line, off-line and through different types of input: TV, radio, internet, social media and newspapers, which can be associated with multilingual discourse, code-switching, code-mixing and a flexible translanguaging policy. Quite often, children can even act as translators for their parents. There are some community bilingual schools that are characterised by bilingual translanguaging practices (Creese \& Blackledge 2010, García et al. 2013, Wiley 2014, Wiley \& García 2016).

Discourse strategies (minimal grasp, expressed guess, repetition, move on and code-switch), parental effort, explicit/implicit language use, management and planning can be used to prevent language shift and to facilitate bilingual/multilingual development (Lanza 2007). FLP is affected by both internal and external social factors. Parents take into consideration social prestige, educational empowerment, and socioeconomic gains when they decide which language(s) to use at home with their children (Curdt-Christiansen 2009).

\section{The sociolinguistic background to the study}

Next, the sociolinguistic situations in the respective countries are considered. The language situation, top-down language policy and ideologies influence a particular set of values, symbols, narratives and emotions that enable Russianspeakers to structure their real-life linguistic experiences.

\subsection{The sociolinguistic situation in Cyprus}

The sociolinguistic situation in Cyprus can be characterised as post-colonial, as Cyprus is a former colony of Britain: English is widespread and is used for communication throughout the island. The local population use two varieties of Greek: Cypriot Greek and Standard Modern Greek. The Russian language is one of the most popular foreign languages in Cyprus, after English. 
The Russian community in Cyprus is one of the largest foreign communities on the island. The first immigrants came there in the late 1990s. Nearly 50,000 people from Russia and the former Soviet republics live in Cyprus permanently; about $75 \%$ of these people are in Limassol. The Russian community in Cyprus is the largest foreign language group. One part of this group is formed by members of mixed marriage families, mainly between Russian women and Greek Cypriot men, with bi- or multilingual Russian-Cypriot Greek children. There are also immigrant families where mostly both partners are Russian and are seeking long-term residence in Cyprus, so they speak Russian at home and English or Greek outside the home.

Russian is a minority language in Cyprus, but it is becoming more and more prestigious nowadays and is widely used. The Cypriots themselves can choose to learn Russian in the lyceum (high school) and public schools or learn it in public or private tutoring centres. Recently, good knowledge of Russian has become a requirement for getting a job in Cyprus, especially in business and tourism. Cyprus has become an attractive destination for Russian people for economic, political, social, geo-political, personal and educational reasons.

There are several public and private Russian-speaking schools in Nicosia, Limassol and Paphos. Russian-speaking children attend either Greek-speaking public schools or English-speaking private schools, and some of them attend private Russian-speaking schools. The Russian language and culture, and bilateral cultural, humanitarian and scientific cooperation with the Republic of Cyprus are actively promoted via the Russian Centre for Science and Culture, which was established in 1978 and is situated in the capital Nicosia. There are various Russian cultural centres and Cyprus-Russian associations. The Cyprus Russian Festival and other cultural events are organised throughout the year and promote Russian language and culture in Cyprus. Both Cyprus and Russia are Orthodox Christian nations, which is a strong cultural bond between them. Russian Orthodox churches are located in Nicosia, Larnaca and Limassol.

The linguistic landscape in Cyprus is changing, becoming more and more multilingual. This is related to the political economy of language and space. Taking into consideration the increased valorisation and commodification of the Russian language (Muth 2017) and the fact that the Russian community in Cyprus is one of the largest on the island, as well as the post-colonial status of Cyprus and widespread usage of English throughout the country, bilingual and multilingual signs reflect the translanguaging practices of both the local population (English and Greek) and the Russian-speakers in Cyprus. The majority of bilingual and multilingual signs can be found in tourist areas, near the sea, in the main shopping areas (shops, hair salons, pharmacies, entertainment venues, banks, currency exchange offices, hotels and other accommodations, restaurants, real estate development offices/advertisements, and car sales and rental firms); Figure 1 is an example of switching between languages for economic reasons. Written in all capitals, "FRESH CYPRUS FISH" is a full English translation of an original Cypriot Greek explanation and an equivalent provided in Russian. 


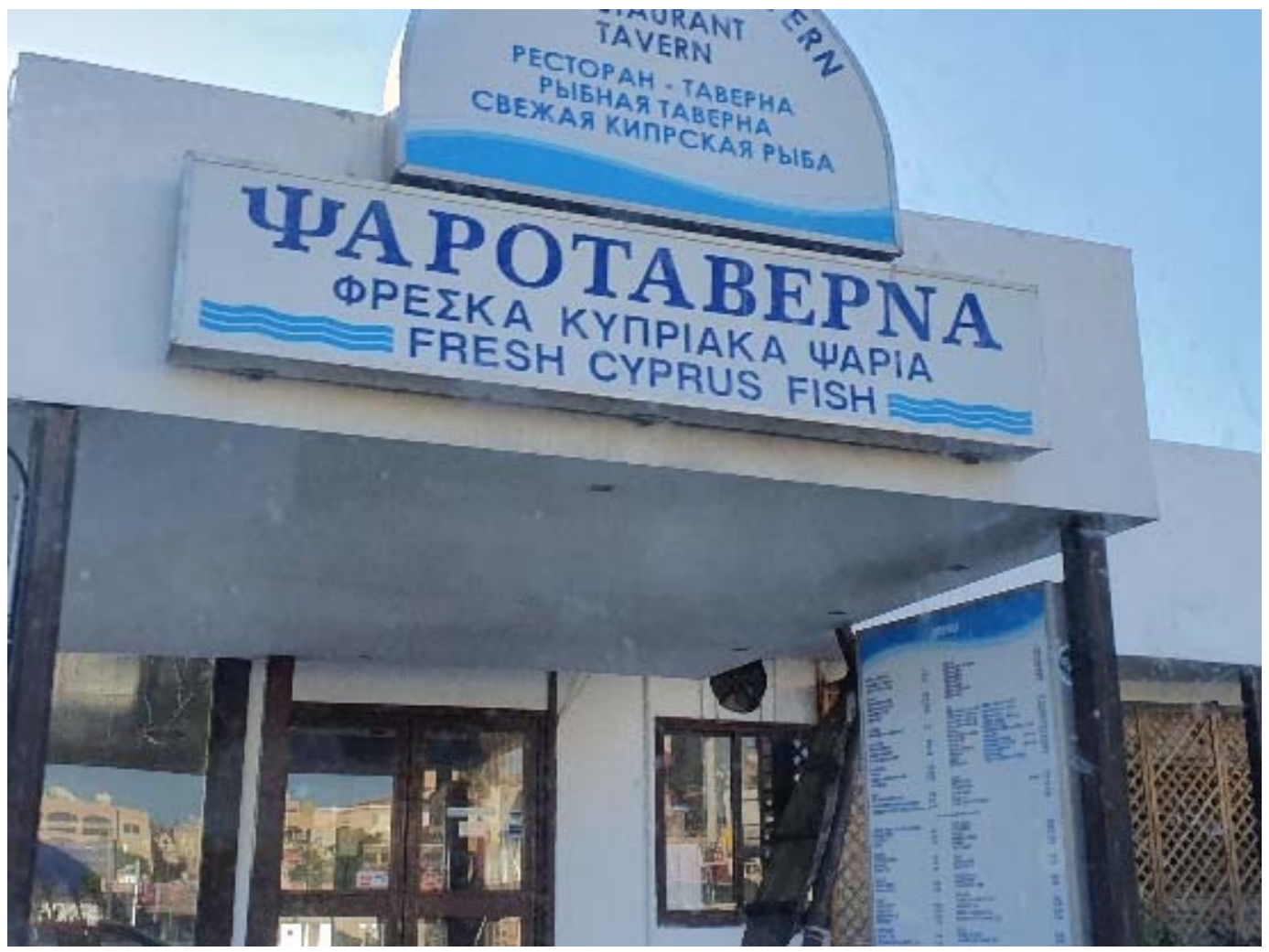

Figure 1. English-Greek-Russian multilingual sign: fish tavern

\subsection{The sociolinguistic situation in Estonia}

The country's large Russian-speaking population was formed mainly through immigration during the Soviet period. The post-Soviet period in Estonia witnessed a language shift: Estonian regained its official status and Russian suddenly lost its strong position and became peripheral. This caused negative attitudes towards the Estonian language and its speakers among Russian-speaking communities.

A control-oriented language policy aimed to purify all language use of any external linguistic influence. According to the nation-building model, the main aim was the introduction of Estonian as the first language for Estonians and as the second language for non-Estonians. The goal was for the use of Estonian as the official language to be normalised, regulated and standardised. Foreign language speakers can gain citizenship only by demonstrating competence in the official language. Besides being requirements for citizenship, language tests were demanded of people in certain positions, e.g. employees in the service sector, teachers, doctors and police. Current Estonian laws and policies do not facilitate the maintenance of the Russian language. Language, citizenship and education laws regulate only the knowledge and use of the Estonian language.

Different educational models for non-Estonian children, the Estonian-language immersion programme in non-Estonian schools and the extending of teaching 
Estonian to kindergartens have created diversity in the language-learning pattern across schools in Estonia. The demand for Estonian-language learning opportunities in schools is rising, and becoming multilingual is considered beneficial in the job market.

In north-eastern Estonia, some towns still have an overwhelming majority of Russian-speakers. Despite the fact that the number of Russian-speakers is quite high, economic weakness does not allow the community to be culturally and politically active.

Globalisation made English a very prominent language in Estonia. Currently the language environment is developing through the interplay of Estonian- and Russian-speech communities in the context of the European Union and the global usage of English as a common lingua franca. The order of the kolm kohalikku keelt "three local languages" in Estonia in the first fifteen years of the $21^{\text {st }}$ century is definitely Estonian, Russian and English (or perhaps Estonian, English and Russian).

The situation in Estonia's linguistic landscape is complex. On the one hand, Estonian receives clear official support and is used significantly in the public sphere. On the other hand, the shift in the perception of Russian from being a marginalised minority language to a commodity with inherent economic value is particularly salient with regard to the service-oriented industries: this is largely reflected in the accommodation of Russian-speaking tourists, potential clients of private businesses, which employ Russian as a marketing strategy. In addition, English as a means of international market-driven commodification and a globalising force is now widely used in the public space.

This situation involving three languages is clearly illustrated in Figure 2. If we start reading it from the left, we notice that to the right of the restaurant "Hutorok трактирь" is located the liquor store "Lime beverage Alkoholipood." On the restaurant sign, the Russian lexical item "hutorok" (small farm) is transliterated into Latin characters (хуторок > hutorok) according to the rules of Estonian spelling. This may signal an appreciation of Estonian or perhaps just obedience to the Place Name Act. Written entirely in capital letters, the Russian word “трактирь” (tavern) is written with ЕРь (b) after the consonant at the end, as it used to be in tsarist Russia. In 1917-1918, the usage of this letter became connected with the "tsarist regime," therefore the Bolsheviks issued a decree about new spelling, and as a result the letter $\mathrm{b}$ remained only as the 28th letter of the alphabet. This re-appropriation of the "useless b" contributes to nostalgic consumerism reminiscent of the Russian empire era. As for the liquor store, its name is written fully in English - "lime beverage" - and its services are in Estonian: "alkoholipood" (a liquor store). Besides all of this linguistic creativity and interesting orthographic choices, the restaurant provides Ukrainian folk cuisine. 


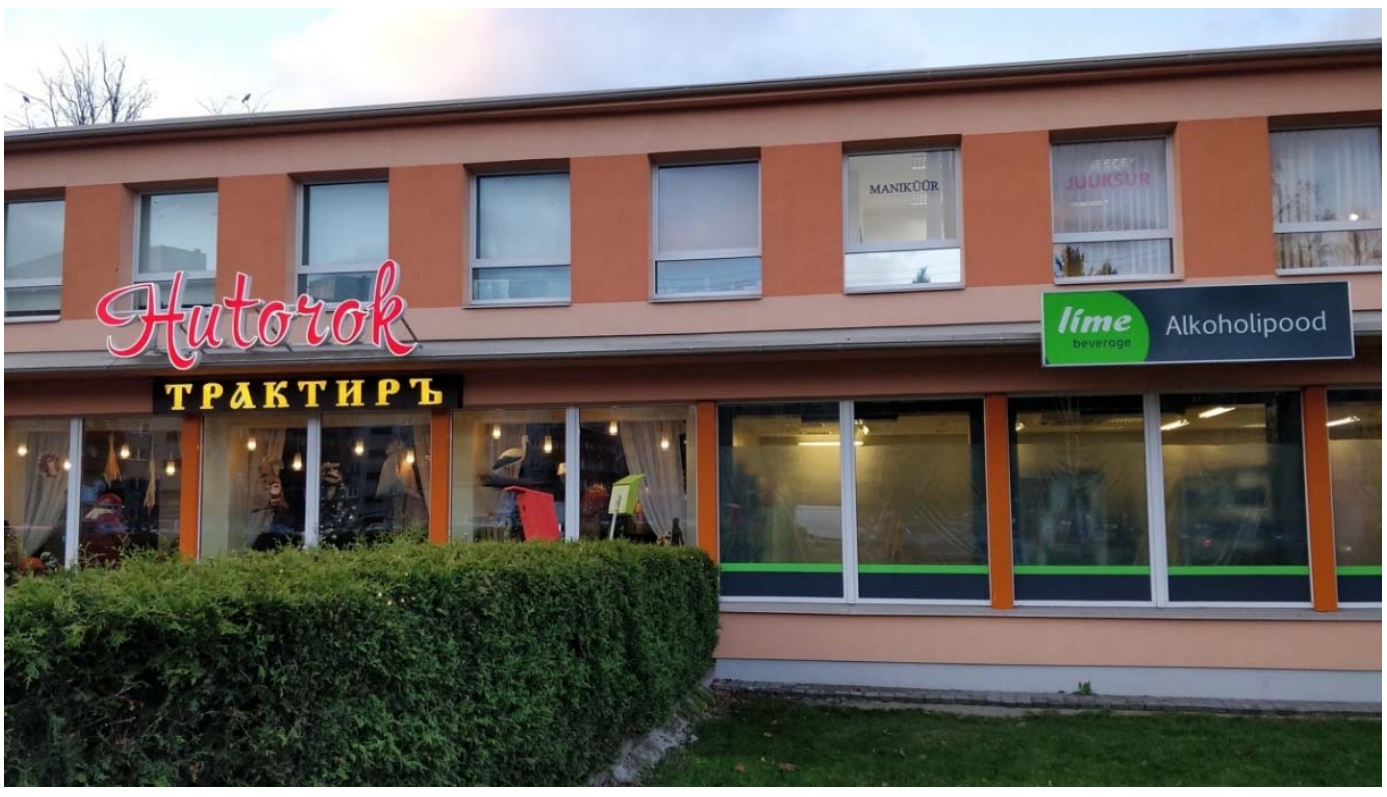

Figure 2. Latinised Russian-Imperial Russian and English-Estonian multilingual signage: tavern and liquor store name signs

\subsection{The sociolinguistic situation in Sweden}

Sweden is nowadays a multilingual country with a large number of immigrants. Russian immigration to Sweden started as early as the 1570 s, when some Russians fled to Sweden to avoid the Oprichnina. Since then, there have been several immigration waves. However, Russian immigrants have never been a large minority group in Sweden. In the early 1990s the Russian diaspora grew bigger because of post-Soviet migration. Since Sweden does not gather any official language statistics, it is very difficult to discover the exact number of people who speak a particular language, including Russian. What complicates the case with the Russian language even further is the fact that many Russian-speakers came from other parts of the former Soviet Union, i.e. from former republics with mother tongues other than Russian. According to Parkvall (2015: 276), there are about 30,000 Russian-speaking people in Sweden, which is $0.3 \%$ of the country's population of around 10 million people. The number of Russian-speaking immigrants is steadily increasing.

Since Russian immigrants do not form one of the main migrant groups, they do not live in distinct Russian communities as they do in several other European countries. Rather, they have settled throughout Sweden, often isolated from each other. Many of them have Swedish partners and live in their spouses' home-towns.

All immigrant Russian children are entitled to study Russian in elementary school (and in some cases even in pre-school), and mother tongue instruction is provided as part of the regular educational system. Depending on where they live, there are varying opportunities for Russian people to maintain their mother tongue 
and for their children to participate in mother tongue instruction. Presently, children have the right to one hour of instruction per week if there are at least five children with the same mother tongue. Russian-language transmission is supported both by official minority language policies and by Russian communities. In addition, Russian-speaking children can learn Russian in different circles and Saturday schools organised by parents and teachers. Additional efforts must be made by Russian-speaking parents, especially since help for Swedish-Russian bilingual families is mostly available in large cities.

It is not surprising that in Sweden the functions of Russian in public signage are reduced to the language of graffiti for personalisation purposes (e.g. "I love you, Olechka") or in museums, libraries and underground stations, as is shown in Figure 3. In the case of the underground station, the letter " $И "$ in the word "ЛИТЕРАТУРА", "literature", is mirrored for stylistic reasons. Russian is also used in tourist attractions visited by many Russians.

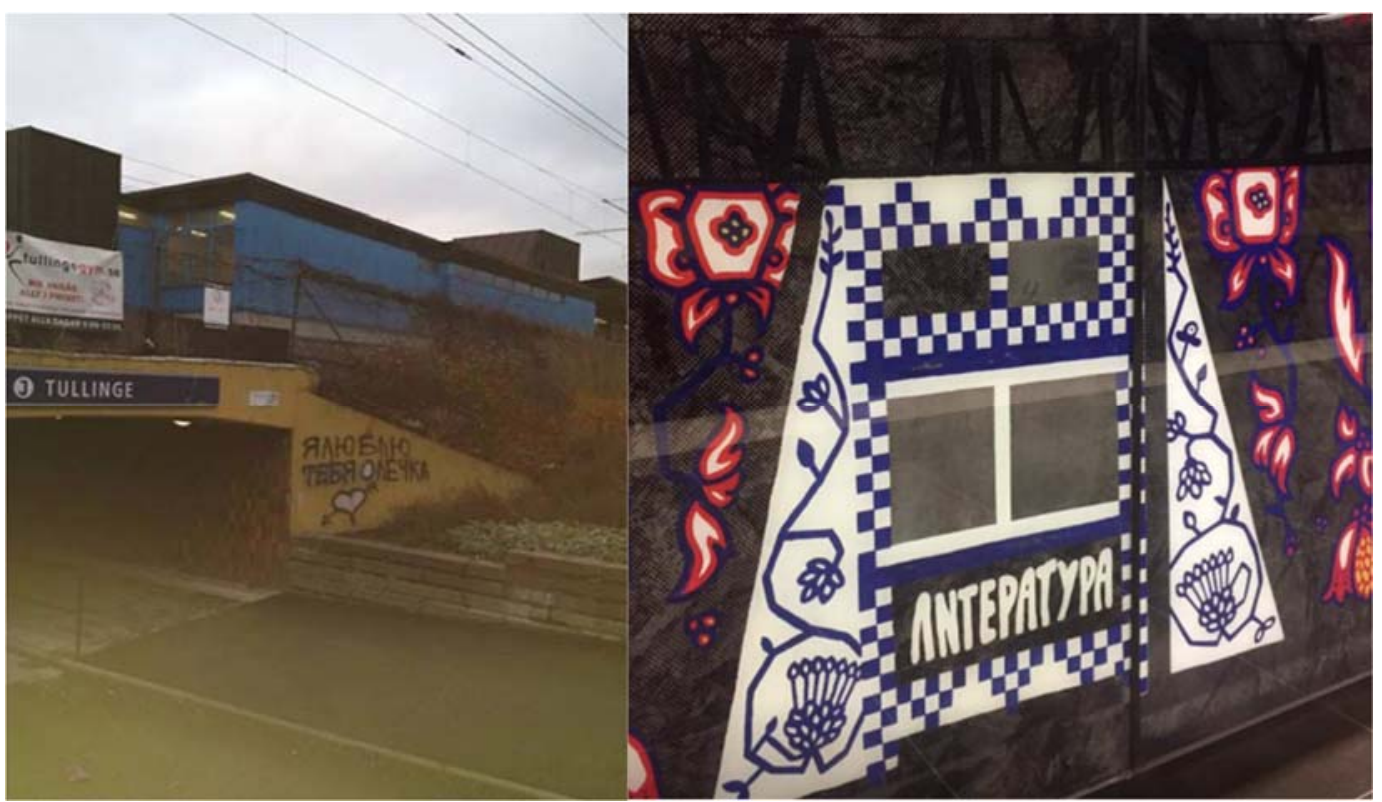

Figure 3. Functions of Russian in Sweden public space: a language of graffiti and underground space

\section{Methodological framework and research design}

Ten families in each country were chosen for a closer look at family language policies and translanguaging strategies. The main criterion for a mixed family to be included in our dataset was that it consisted of an official language- (Cypriot Greek, Estonian- or Swedish-) speaking partner (a father) and a Russian-speaking partner (a mother) who lived together with their child(ren) as one household, and that the family members were not only inclined towards merging with the mainstream society linguistically and culturally but also considered it important to preserve the Russian language and culture. Notably, often the father's relatives welcomed such an approach. 
As a non-manipulative methodology, our ethnographic participant observation aimed to observe language use in the widest possible range of situations: during family meals, at indoor and outdoor entertainment activities, and for completing homework assignments. Our aim was to search for spontaneous translanguaging and to understand its nature as an essential part of bilingual language practice, depending on a particular socio-linguistic and socio-cultural context as well as translanguaging space. In this paper, we purposely do not include examples of conversations in which a bilingual child spoke to a Russian-speaking family member who was monolingual (for example, a grandmother who arrived from Russia for a short visit or lived in another, mainly monolingual part of the country, in the case of Estonia) and during which the number of language switches was very low or even non-existent. On the one hand, this shows the child's ability to accommodate to the linguistic behaviour of his/her interlocutor and supports the idea that translanguaging might be self-regulated, depending on the context and the communication/interaction. On the other hand, the child might be mostly a listener in such situations (which was true at least in the dialogues we had available), might talk about familiar matters or respond to what was said, and ask for someone else's language help.

Using ethnographic participant observations and spontaneous oral bilingual/multilingual production, our study attempted to describe how communication was managed through translanguaging activities in multilingual Russian-speaking families in Cyprus, Estonia and Sweden. The researchers made regular home visits to the families. We tried to make sure that between 18 and 20 hours was spent with each family during the six months of the study (this fieldwork ended right before the lock-downs in March 2020). The focus was on FLP, the language repertoires of the family members, construction and negotiation of implicit/ explicit FLP, and translanguaging.

Discourse analysis was used as an analytical tool in order to analyse recurring issues, patterns regarding language ideologies and practices, attitudes, identities, FLP enactment, ideologies and practice, and translanguaging space. We tried to implement a qualitative discourse/conversation analytic approach (Walsh et al. 2011, Partington et al. 2013) for data analysis. We took into account that while divergent language choices we encountered on a typical observation day might seem inconsequential, they nevertheless constructed the translanguaging space in which families lived, communicated family language policy-making and conveyed family language ideologies.

The functions of translanguaging were categorised into types that would help to explain the multifunctional nature of translanguaging. We did not find counting statistical data on spontaneous language choices a useful tool here because relying on a set of numbers about multiple forces in constant simultaneous interplay, such as speakers' linguistic competences, communicative goals and functions, without understanding the social context of the interaction and the relationships between the interlocutors, does not really contribute to understanding the enduring 
translanguaging spaces in which mixed families live. In addition, we implemented an in-depth ethnographic landscape analysis of visible semiotic signs at home and in public spaces (see Figures 1-3 as an example), trying to interpret their indexicality and deeper layers of meaning in relation to multilingual situations in the countries under investigation in line with the principles of the symbolic construction of public spaces (Blommaert 2013).

\section{Translanguaging space and language management in observed data}

Our results show that parents in minority and immigrant contexts realised quite soon the importance of early child literacy experiences at home. The parents tried to enhance these experiences both in Russian and in the dominant language of the country via (in)direct teaching through child-directed speech and meaning-focused shared activities. According to the families, the usage of flexible bilingual and bicultural materials aided in raising a bilingual and bicultural child with an integrated linguistic and cultural system.

We examined the choices of books and other printed reading materials at home: whether they were in Russian, the majority language of the country (Cypriot Greek, Estonian or Swedish) and/or English (and other languages). We found that not every family had strong reading habits. However, a multilingual translanguaging space on a bookshelf might have been created so that various Russian, English and majority language books indicated the coexistence of diverse languages and cultures in the home. The families often preferred Russian fairy tales because of their general caring, educative and benevolent nature. Some families mentioned that they needed to adjust the language in the fairy tales and the stories read to the children, for example by removing "old words" or replacing complex syntactic constructions with easy ones, to ensure that the children would understand the plots of the stories. Notably, the translanguaging space included not only reading materials, but also writing materials.

Multilingual space might also be created with the help of various symbols and cultural attributes: not only Russian cultural artefacts (e.g. Russian Matryoshka dolls; Khokhloma, a Russian wood-painting handicraft style and national ornament; Gzhel, a Russian style of blue and white ceramics; and a samovar or a kitchen tool used as a batterie de cuisine) as well as shawls, Russian kosovorotki (peasant shirts) and Russian forage caps. Russian-speaking participants tried to maintain strong links with their homeland and brought different symbolic cultural items from Russia. At home, these were put together with items of the majority and often Anglo-American cultures, which could be a reflection of a translanguaging space. This represented a new unified family culture policy formed on the basis of separate cultural spaces, where children were introduced to not only linguistic and cultural concepts but also historical elements shared by the two countries. By being included naturally in the everyday life of the child, the Russian artefacts became as natural a part of the child's life as the Swedish/(Cypriot) Greek/Estonian ones. 
As we mentioned in Section 4, we collected photographic data of the linguistic landscapes. Our aim was to examine whether multilingual translanguaging space in Russian-speaking families is a (possible) reflection of the multilingual translanguaging space of the society. The location, layout and index of signs in the real space of Cyprus, Estonia and Sweden provided information about social change, complexity and super-diversity on the individual family level. In Cyprus, we found that there are many bilingual and multilingual public signs (Figure 1), which provide evidence of the emergent multilingualism in the country that affects language policy, the status of minority/immigrant language, their use, maintenance and intergenerational transmission. The situation in Estonia's linguistic landscape is complicated (Figure 2). The before data show how Estonian and Russian are combined on multilingual signs. If to touch upon distinctive features of particular images and pay attention to the orthography and graphic representation of Estonian and Russian, then their linguistic forms on multilingual signs are sometimes combinations of the two languages or of the Latin and Cyrillic alphabets, or even compromise forms, new creations, playful spellings or mixed structures. Russian in today's Sweden is basically not present in the public space except for some very specific situations (Figure 3).

The approach to switching between the languages adopted by the research participants, or what we call translanguaging in this paper, is considered to be a norm in conversations between multilingual individuals in a family circle because the content is available to all the interlocutors. Our longitudinal observations show that both parents and children alternated languages because it allowed them to create a shared translanguaging space, which facilitated interaction among multilingual family members and allowed the full use of available linguistic repertoires, where they could smoothly make meaning comprehensible and establish inclusive family membership. In Example 1, a mother is sending her children to school. She urges one child, who is late all the time, to hurry; the child adapts her language choice to the preference of the mother but still uses both Russian and Cypriot Greek.

(1) Cypriot Greek data:

- Быстрее собирайтесь в школу.

The mother uses Russian, translated as "Get ready for school faster."

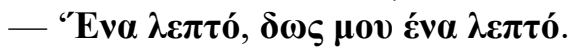

The child uses Greek in order to answer, translated as "One minute, give me one minute!"

- Ты всё время опаздываешь!

The mother continues to speak in Russian, translated as "You are late all the time!"

- Hет, неправда нóvo би́ $\boldsymbol{\varepsilon \varepsilon \rho . . . ~}$

The child uses both Russian and Greek, translanguaging in order to respond, translated as "No, it is not true, only today."

Such switching happens mostly on an unmarked basis, according to our data from the three countries: in other words, speakers are conscious of what code is 
expected. Mostly translanguaging happens when people relax and do not control their language use, as they have adjusted to one another and know well what is acceptable with particular multilingual conversation partners. This is where translanguaging becomes flexible multilingualism. We found that different factors contributed to translanguaging milieu creation at home; they mainly were the multilingual competence of family members; parents' positive and sometimes even encouraging attitude towards it, which makes children feel that it is a common conversational repertoire shared and accepted by the family; and frequent association of a majority- or English-language term with a particular phenomenon in everyday life, whereas the level of competence in these languages did not restrict or facilitate translanguaging. Our Russian-speaking family members had very different educational backgrounds, levels of proficiency in the mainstream language - Cypriot Greek, Estonian and Swedish - and in English, and various job experiences. But, with the help of translanguaging, these multilingual speakers created (new) identities and participated in multilingual discursive practice in a meaningful way. The families created shared interactions, expanded with the help of different linguistic resources, in which all family members were able to participate on an equal basis and make proper interpretations, as in Example 2, in which a dialogue involves speakers of younger and older generations using Greek, Russian and English:

(2) Cypriot Greek data:

Daughter 1: Пó $\mu \varepsilon \theta \boldsymbol{\theta} \dot{\lambda} \boldsymbol{\alpha \sigma \sigma \alpha}$ !

Let's go to the sea!

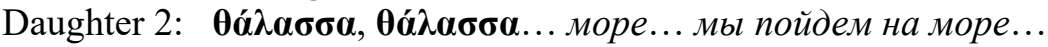

Sea, sea... sea... we will go to the sea...

Grandmother: Надо говорить по-русски!

You should speak Russian!

Daughter 1: (to Grandmother): Да, бабушка! Пошли на море; надо взять полотенца.

Yes, granny! Let's go the sea; we need to take the towels.

Grandmother: Да, и воду не забудьте!

Yes, and do not forget water!

Daughter 2: “OK, let's go!"

We suggest that social networking is likely to reinforce the ability to translanguage, indexing divergent language choices about which word to use when talking about a particular sort of thing, because what we have noticed is that one feature common in the speech of those Russian-speaking family members who networked with majority-language speakers of different ages outside the home was a tendency to express in one word, several words or a short phrase a spontaneous feeling or reaction. Children also engaged in similar situations when they started negotiating their linguistic roles: it was hard to detect if it was a parent who started saying a particular word simply as a statement of fact and this shaped the behaviour of a child, or if a teenager had brought a phrase home from school or his/her social network and initiated its use among younger siblings and parents. 
Occasional Swedish interjections appeared in otherwise Russian conversations (or situations), for instance: men asså "oh, ass" (when a sandwich fell off the table), oops! "oops" (when noticing that an SMS was sent to the wrong number), oh nej! "oh no" (when discovering that the shop closed five minutes ago and now it is too late to go), and va? "what?" (when surprised). In Estonia, Estonian exclamations and other expressive and emotional utterances are very attractive as a locally labelled style: aitab küll! "that is enough!" (referring to an activity that must stop), mida? "what?" (used in so many different types of situations that sometimes it is unclear what discourse role is actually being assigned to it: associated with difficulties, surprise, disagreement, referring to objects/situations/etc.), and nii "so" (also used for many different purposes). In Cyprus, Russian-speaking family members use English expressive and emotional utterances (e.g. "please", "relax", "super" and "the best!") if their relationships have stronger links with an international community. English is used as a lingua franca (sometimes interchangeably with Russian) and locally relevant social meanings occur regularly if Russian-speakers work or communicate closely with Cypriots in Cypriot Greek.

The analysis of natural conversational data produced by mixed families in Cyprus showed that very often the participants used English or Greek in the names of shops, and for labels and goods. In Cyprus, translanguaging is a common phenomenon, and sometimes it was easier for the participants to use a fixed phrase or chunks of language in English, which is widespread throughout the island, or Cypriot Greek to fill in lexical gaps, than it was to spend time searching for a suitable equivalent and or a descriptive translation in Russian. A pragmatic function of translanguaging in these countries is to cover semantically specific terminology, as in Example (3), which is an excerpt from a Russian-speaking mother's speech regarding a specific shop where she buys different types of health products (note that here English language elements are not integrated morphologically into a Russian matrix):

(3) Cypriot Greek data:

B organic shop покупаю, без пальмового масла.

I buy it in an organic shop, without palm oil.

Consider also the shop names specifically used in a dialogue between family members in Example 4. Translanguaging of this kind leads to full-fledged borrowing of such terms:

(4) Cypriot Greek data:

- Какие магазины сегодня работают?

Which shops are open today?"

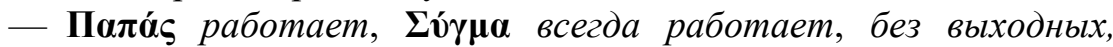
обедов и праздников!

The Papas shop is open, and Sigma is always open, seven days a week, without lunch breaks, and on holidays! 
In the case of translanguaging it is strange to talk about the grammar because we are not dealing with properly formed phrases or sentences. But what makes Estonian data different from Cypriot is the (full) morphosyntactic integration of Estonian items into the Russian matrix, as in Example 5, in which, as the endings of gender agreement in Russian adjectives indicate, the Estonian nouns toit "food" and kohvik "cafe" are treated as Russian masculine nouns of the second declension class. In addition, the Estonian noun kohvik follows the declension principles of the accusative case, as required by Russian monolingual grammar rules:

(5) Estonian data:

Какой toit предлагается в новом kohvik-e?

What food is offered in the new café.PREP?

In Sweden, Russian-speaking family members insert Swedish words or phrases when they either have no Russian equivalents (Example 6), or they do not remember the exact translation at a particular moment, as in Example 7, in which a child describes her school experiences.

(6) Swedish data:

Надо написать inköpslista.

I need to write out a shopping list.

(7) Swedish data:

Мы на träslöjd такое делали.

We did this in labour class.

As particular circumstances and Swedish realities affect Russian-speakers, those Swedish words are mainly used, as they are difficult to translate into Russian. Similarly to Russian-Estonian data, a Swedish word might be morphologically integrated into Russian: as the endings of a Russian verb and a Russian adjective show, in Example 8, a Swedish noun is treated as having neutral gender. This might also be called intentional translanguaging, as sometimes it is not only easier to insert a Swedish word, as in Example 8 närvaro "attendance", since the Russian equivalent is not as easily accessible, but it is also important to emphasise its official significance:

(8) Swedish data:

Он всегда на уроки ходил. У него närvaro было стопроцентное.

He always attended lessons. His attendance was one hundred percent.

In Example 9, Swedish elements are treated as majority-language schoolrelated concepts that are used in preference to the Russian equivalents, whereas the Swedish insertion prov "test" behaves as a Russian masculine noun, cf. with mecm "test," a Russian masculine noun with zero-ending:

(9) Swedish data:

У нас был svenska prov nо särskrivning.

We had a Swedish spelling test. 
In Estonia, in Example 10, when chatting about school matters, a child starts excitedly describing them:

(10) Estonian data:

Из-за о̃petaja такой плохой tuјu у меня сегодня.

Because of the teacher I am in such a bad mood today.

Even within one short sentence, two switches occurred that show the intensity of Estonian nouns. One of the insertions, tuju "mood," has masculine gender agreement with the Russian adjective, as the ending of the latter shows: плох-ой "bad (MASC)."

Estonian nouns might also be adopted with the help of a demonstrative pronoun, as in Example 11, where a Russian word points to the masculine gender of an insertion:

(11) Estonian data:

А мне нравится этот luuletus.

But I like this poem.

Translanguaging is defined functionally and consists of languages relevant to the current situation. Our comparative data demonstrate that nouns and interjections are usually switched, and then other parts of speech that have their place in the "switchability hierarchy" (Appel \& Muysken 1987: 170-171), but these are outside the scope of this paper. What we found is that when the mothers used translanguaging themselves and did not correct their children's mixing of languages, the children seemed to have more relaxed attitudes to language mixing and did not seem to reflect on what language to choose but just chose the language that was most accessible at the moment. Thus, while most parents wanted to preserve the quality of the Russian language and transmit it to their children, they sometimes let the children use the language that was most convenient at particular moments. Some parents noted that over time more domains were replaced by the majority language, which led to a language shift. These parents went to a lot of trouble to provide their children with the benefits of not only becoming but also staying bilingual.

\section{Discussion}

The concept of translanguaging helped us to capture the dynamic nature of languaging in Russian-speaking families. We implemented a social process approach, with the focus on translanguaging and translanguaging space, potential language variation and change. We dealt with diverse geographical and linguistic contexts, various families and language combinations related to different attitudes, beliefs, self-efficacy, expectations and behaviours.

We carried out a linguistic landscape analysis, where translanguaging space and multi-faceted semiotic resources, multimodality and discoursivity are ideological constructs and social events. We found some differences and 
similarities between the study participants in the three countries under investigation regarding translanguaging practices. Sociolinguistic situations in the countries, the size of the Russian community, the status of Russian (minority, immigrant, lingua franca) - all these factors affected the translanguaging space at the levels of the society and home, family domain.

The sociolinguistic realities had a potential impact on translanguaging and intercultural communication of the participants. In Cyprus, translanguaging was a common phenomenon in linguistic landscape and written communication. Due to post-colonial situation, there are many bilingual, English-Greek signs, and the local population uses two languages, (Cypriot) Greek and English, interchangeably. If in Cyprus Russian can be characterised as a new lingua franca in public signage and discourse, then in Sweden, it meets more needs of a marginalised minority group. In Estonia, multilingual public spaces generate power struggles and the language ideological dimension in a de jure monolingual society. All the three linguistic landscapes clearly illustrated that Russian and dominant languages serve different needs at home of multilingual Russian-speaking families and in the society, covering these adequately. All this taken together definitely has had an impact on the language choice, use and attitudes of Russian families and their translanguaging space reflected the one of the mainstream society.

The translanguaging space created at home is based on pragmatically practical reasons of mutual understanding, getting the message across, functional and communicative purposes. More importantly, in Cyprus and Sweden, translanguaging allowed keeping linguistic links with homeland, broadening the horizons of children, and developing their intercultural competence, awareness and communication skills.

Translanguaging was implemented as a communicative function, not a variety or fixed code, a social practice based on a dynamic system, the pragmatic use of linguistic and other (multimodal) resources, a repertoire including accommodation and strategic skills. There was an interplay between children's and parents' multiple language use, family language policy, language choices, management, informed and useful decision, unique struggles and challenges that parents face.

In Estonia and Sweden, both parents and children were especially creative in the use of grammatical resources for efficient and successful translingual communication. In Cyprus, all the three available codes of the repertoires were commonly employed. In all the three countries, children played overt and covert roles in their own language use and many times affected parental language choices. Via practising translanguaging children become aware of the power dynamics of the languages involved, and they are able to develop personal and communal agency. Thus, the children developed translingual communicative capacity and mediation competence.

In Cyprus and Sweden, mothers in mixed-marriage families are the key agents for the heritage language use, maintenance and transmission. Their bilingual children are often the initiators of translanguaging as they speak two languages and 
have to communicate with their Russian-speaking mothers and majority languagespeaking fathers. They can also be mediators between their two parents. To conclude, both linguistic and non-linguistic factors affected translanguaging strategies and the construction of the traslanguaging space in Russian-speaking families in Cyprus, Estonia and Sweden.

\section{Conclusions}

This study aimed to look into translanguaging space, societal changes, sociopolitical structures in Cyprus, Estonia and Sweden, family language policy, the interplay between language ideologies and language practices and management, language use, maintenance and transmission, linguistic and cultural values, and certain incongruities in language practices and ideologies, taking into consideration both linguistic and non-linguistic factors, and macro- and micro-factors. This linguistic ethnography project investigated translanguaging practices, the use of multimodal resources, and the analysis of linguistic landscape.

It is impossible to cover all that we know about the Russian language in the interplay with local majority languages and translanguaging but, based on our results, we argue that a new norm of the Russian language (for the Swedish case, see Ringblom 2012; for the Estonian case, see Zabrodskaja 2009) is being developed in all the three settings and this topic will definitely be studied further. It also seems to be likely that the socio-linguistic situation in each country affects language attitudes and multilingual interaction practices in majority languageRussian bilingual families.

Translanguaging takes place both at the word and intra-sentential levels. In some contexts, longer insertions are a marked practice and these contexts need to be investigated further in order to be able to draw any definite conclusions. Yet, it seems that in families that see translanguaging as a natural way of communication, such strategies are also more accepted and more widely used. Even though it may be argued whether it is beneficial from the language transmission point of view, language change has not happened in such families, probably because of the positive attitude to the Russian language and because of the use of it even outside the home domain.

We believe that while translanguaging practices can be used in family conversational contexts and can contribute to the creation of a rich and positive family repertoire, parents should also be aware of the fact that a language shift can happen more quickly than they expect, and thus it is important for parents to provide numerous opportunities for practising Russian as the L1 (see also Ivanova \& Zabrodskaja 2021). Even though both the children and the adults were able to control which language they used and in what situations, sometimes this became problematic.

Instead of continuing to use terminology from the dominant, official language, it may be more appropriate to introduce the necessary terminology from the Russian language, to make the child familiar with it and able to use it in his/her own 
communication; otherwise, children will not be able to function in Russian in school, and the number of such communicative contexts where Russian is not used will continue to grow. This requires a systematic approach in order to succeed and to have a clear understanding that while translanguaging practices can support and expand dynamic multilingualism and integrate Russian as a minority language into a wider societal context, from the Russian intergenerational transmission perspective, translanguaging can be highly controversial since it can enhance language change when used in more and more domains, especially when families do not make conscious choices regarding specific language management and have "laissez-faire" attitudes regarding language choices and expanding translanguaging within the family context.

Translanguaging can be seen both as a threat and an opportunity for minority language development, its protection and its promotion (Cenoz \& Gorter 2017). As the norm becomes blurred, we suggest that, in early childhood, languages should be separated as much as possible, but more research needs to be done on this topic.

(C) Sviatlana Karpava, Natalia Ringblom and Anastassia Zabrodskaja, 2021
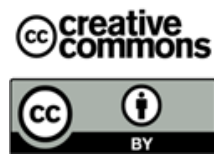

This work is licensed under a Creative Commons Attribution 4.0 International License https://creativecommons.org/licenses/by/4.0/

\section{Author contributions}

Authors 1, 2 and 3 all contributed equally and should be considered co-first authors.

\section{Acknowledgements}

This article was supported by basic funding for research areas of national significance at the Institute of Estonian and General Linguistics of the University of Tartu. The theoretical results are part of the project IUT20-3 "Sustainability of Estonian in the era of globalisation" (EKKAM). Natalia Ringblom would like to acknowledge the support of the Åke Wiberg Foundation in conducting this research. Data collection and analysis in Cyprus were supported by the internal start-up funding programme of the University of Cyprus: Heritage Language Maintenance, Variation and Change (2020-2022).

\section{REFERENCES}

Appel, Rene \& Pieter Muysken. 1987. Language Contact and Bilingualism. London: Edward Arnold.

Blommaert, Jan. 2013. Ethnography, Superdiversity and Linguistic Landscapes. Chronicles of Complexity. Bristol: Multilingual Matters.

Canagarajah, Suresh. 2011. Translanguaging in the classroom: Emerging issues for research and pedagogy. Applied Linguistics Review 2 (1). 1-28.

Canagarajah, Suresh. 2015. Clarifying the relationship between translingual practice and L2 writing: Addressing learner identities. Applied Linguistics Review 6 (4). 415-440.

Cenoz, Jasone \& Durk Gorter. 2011. Focus on multilingualism: A study of trilingual writing. Modern Language Journal 95 (3). 356-369. 
Cenoz, Jasone \& Durk Gorter. 2015. Multilingual Education: Between Language Learning and Translanguaging. Cambridge: Cambridge University Press.

Cenoz, Jasone \& Durk Gorter. 2017. Minority languages and sustainable translanguaging: Threat or opportunity? Journal of Multilingual and Multicultural Development 38 (10). 901-912.

Cenoz, Jasone \& Durk Gorter. 2019. Multilingualism, translanguaging, and minority languages in SLA. The Modern Language Journal 103 (19). 130-135.

Creese, Angela \& Adrian Blackledge. 2010. Translanguaging in the bilingual classroom: A pedagogy for learning and teaching. Modern Language Journal 94 (1). 103-115.

Curdt-Christiansen, Xiao Lan. 2009. Visible and invisible language planning: Ideological factor in the family language policy of Chinese immigrant families in Quebec. Language Policy 8 (4). 351-375.

Curdt-Christiansen, Xiao Lan. 2013. Negotiating family language policy: Doing homework. In Mila Schwartz \& Anna Verschik (eds.), Successful Family Language Policy: Parents, Children and Educators in Interaction, 277-295. Dordrecht: Springer.

Curdt-Christiansen, Xiao Lan. 2014a. Family language policy: Is learning Chinese at odds with leaning English in Singapore. In Xiao Lan Curdt-Christiansen \& Andy Hancock (eds.), Learning Chinese in Diasporic Communities: Many Pathways to Being Chinese, 35-58. Amsterdam: John Benjamins.

Curdt-Christiansen, Xiao Lan. 2014b. Planning for development or decline? Education policy for Chinese language in Singapore. Critical Inquiry in Language Studies 11 (1). 1-26.

Curdt-Christiansen, Xiao Lan. 2016. Conflicting language ideologies and contradictory language practices in Singaporean bilingual families. Journal of Multilingual and Multicultural Development 37 (7). 694-709.

García, Ofelia. 2009. Bilingual Education in the 21 ${ }^{\text {st }}$ Century: A Global Perspective. Chichester: Wiley-Blackwell.

García, Ofelia, Zeena Zakharia \& Bahur Otcu. 2013. Bilingual Community Education and Multilingualism: Beyond Heritage Languages in a Global City. Bristol: Multilingual Matters.

García, Ofelia \& Camila Leiva. 2014. Theorizing and enacting translanguaging for social justice. In Adrian Blackledge \& Angela Creese (eds.), Heteroglossia as Practice and Pedagogy, 199-216. Heidelberg: Springer.

García, Ofelia \& Li Wei. 2014. Translanguaging: Language, Bilingualism and Education. London: Palgrave Macmillan.

García, Ofelia \& Tatyana Kleyn. 2016. Translanguaging with Multilingual Students: Learning from Classroom Moments. New York: Routledge.

García, Ofelia, Susana Johnson \& Kate Seltzer. 2016. The Translanguaging Classroom: Leveraging Student Bilingualism for Learning. Philadelphia: Caslon.

Gardner-Chloros, Penelope. 2010. Content and code-switching. In Raymond Hickey (ed.), The Handbook of Language Contact, 188-207. Oxford: Wiley-Blackwell.

Gort, Mileidis \& Sabrina Francesca Sembiante. 2015. Navigating hybridized language learning spaces through translanguaging pedagogy: Dual language preschool teachers languaging practices in support of emergent bilingual children's performance of academic discourse. International Multilingual Research Journal 9 (1). 7-25.

Haugen, Einar. 1950. The analysis of linguistic borrowing. Language 26 (2). 210-231.

Heine, Bernd \& Tania Kuteva. 2005. Language Contact and Grammatical Change. Cambridge: Cambridge University Press.

Hélot, Christine \& Anne-Marie de Mejía. 2008. Introduction: Different spaces-different languages integrated perspectives on bilingual education in majority and minority settings. In Christine Hélot \& Anne-Marie de Mejía (eds.), Forging Multilingual Spaces: 
Integrated Perspectives on Majority and Minority Bilingual Education, 1-30. Bristol: Multilingual Matters.

Ivanova, Olga \& Anastassia Zabrodskaja. 2021. Family language policy in Russian-Estonian and Russian-Spanish multilingual settings. Russian Journal of Linguistics 25 (4). 1047-1070.

Jewitt, Carey. 2016. The Routledge Handbook of Multimodal Analysis. London: Routledge.

Karpava, Sviatlana, Natalia Ringblom \& Anastassia Zabrodskaja. 2019. Translanguaging in the Family Context: Evidence from Cyprus, Sweden and Estonia. Russian Journal of Linguistics 23 (3). 619-641.

Karpava, Sviatlana, Natalia Ringblom \& Anastassia Zabrodskaja. 2020. Family language policy leading to multilingual home literacy environment: Evidence from interviews with Russian-speaking mothers in Cyprus, Estonia and Sweden. HumaNetten 45. 11-39.

King, Kendall A. \& Lyn Fogle. 2006. Bilingual parenting as good parenting: Parents' perspectives on family language policy for additive bilinguals. International Journal of Bilingual Education and Bilingualism 9 (6). 695-712.

King, Kendall A., Lyn Fogle \& Aubrey Logan-Terry. 2008. Family language policy. Language and Linguistics Compass 2 (5). 907-922.

Lane, Pia. 2010. We did what we thought was best for our children: A nexus analysis of language shift in a Kvan community. International Journal of Social Language 202. 63-78.

Lanza, Elizabeth. 2007. Multilingualism in the family. In Peter Auer \& Li Wei (eds.), Handbook of Multilingualism and Multilingual Communication, 45-67. Berlin: Mouton de Gruyter.

Lefebvre, Henri. 1991. The Production of Space. Oxford: Blackwell.

Lewis, Gwyn, Bryn Jones \& Colin Baker. 2012. Translanguaging: Origins and Development from School to Street and Beyond. Educational Research and Evaluation: An International Journal on Theory and Practice 18 (7). 641-654.

Li Wei. 2011. Moment analysis and translanguaging space: Discursive construction of identities by multilingual Chinese youth in Britain. Journal of Pragmatics 43 (5). 1222-1235.

Li Wei. 2018. Translanguaging as a practical theory of language. Applied Linguistics 39 (1). 9-30.

Llurda, Enric, Josep-Maria Cots \& Lurdes Armengol. 2013. Expanding language borders in a bilingual institution aiming at trilingualism. In Hartmut Haberland, Dorte Lonsman \& Bent Preisler (eds.), Language Alternation, Language Choice, and Language Encounter in International Tertiary Education, 203-222. Dordrecht: Springer.

Lowman, Chris, Tangimai Fitzgerald, Patsy Rapira \& Rahera Clark. 2007. First language literacy skill transfer in a second language learning environment: Strategies for biliteracy. SET 2. 24-28.

Makalela, Leketi. 2015. Translanguaging as a vehicle for epistemic access: Cases for reading comprehension and multilingual interactions. Per Linguam-Journal for Language Learning 31 (1). 15-29.

Matras, Yaron. 2009. Language Contact. Cambridge: Cambridge University Press.

May, Stephen. 2014. The Multilingual Turn: Implications for SLA, TESOL, and Bilingual Education. New York: Routledge.

Muth, Sebastian (ed.). 2017. Commodification of Russian. [Special issue]. Russian Journal of Linguistics 21 (3).

ÓhIfearnáin, Tadhg. 2013. Family language policy, first language Irish speaker attitudes and communitybased response to language shift. Journal of Multilingual and Multicultural Development 34 (4). 348-365.

Otheguy, Ricardo, Ofelia García \& Wallis Reid. 2015. Clarifying translanguaging and deconstructing named languages: A Perspective from linguistics. Applied Linguistics Review 6 (3). 281-307. 
Parkvall, Mikael. 2015. Sveriges språk i siffror [Swedish in Numbers]. Språkrådet. Morfem. (In Swedish)

Partington, Alan, Alison Duguid \& Charlotte Taylor. 2013. Patterns and Meanings in Discourse: Theory and Practice in Corpus-Assisted Discourse Studies (CADS). Amsterdam: John Benjamins.

Pennycook, Alastair \& Emi Otsuji. 2014. Metrolingual multitasking and spatial repertoires: 'Pizza mo two minutes coming.' Journal of Sociolinguistics 18 (2). 161-184.

Pérez Báez, Gabriela. 2013. Family language policy, transnationalism, and the diaspora community of San Lucas Quiaviní of Oaxaca, Mexico. Language Policy 12 (1). 27-45.

Poplack, Shana \& David Sankoff. 1984. Borrowing: The synchrony of integration. Linguistics 22 (1). 99-135.

Ringblom, Natalia. 2012. The emergence of a new variety of Russian in a language contact situation. In Kurt Braunmüller \& Christoph Gabriel (eds.), Multilingual Individuals and Multilingual Societies, 63-80. Amsterdam, Philadelphia: John Benjamins.

Simpson, Jane. 2013. What's done and what's said: Language attitudes, public language activities and everyday talk in the Northern Territory of Australia. Journal of Multilingual and Multicultural Development 34 (4). 383-398.

Walsh, Steve, Tom Morton \& Anne O'Keeffe. 2011. Analysing university spoken interaction: A CL/CA approach. International Journal of Corpus Linguistics 16 (3). 325-344.

Wiley, Terrence G. 2014. Policy considerations for promoting heritage, community, and Native American languages. In Terrence G. Wiley, Joy Kreeft Peyton, Donna Christian, Sarah Catherine K. Moore \& Na Liu (eds.), Handbook of Heritage, Community, and Native American Languages in the United States: Research, Policy, and Educational Practice, 45-53. New York: Routledge/Taylor \& Francis.

Wiley, Terrence G. \& Ofelia García. 2016. Language policy and planning in language education: Legacies, consequences, and possibilities. The Modern Language Journal 100 (S1). 48-63.

Zabrodskaja, Anastassia. 2009. Russian-Estonian Language Contacts: Grammatical Aspects of Language Use and Change. Tallinn: Tallinn University. http://www.tlulib.ee/files/arts/93/ Zabro6d6de71d850daacb358353791fb9bc95.pdf (accessed 19 April 2021).

\section{Article history:}

Received: 12 May 2021

Accepted: 20 October 2021

\section{Bionotes:}

Sviatlana KARPAVA $(\mathrm{PhD})$ is a Lecturer in Applied Linguistics/TESOL and Linguistics Section Coordinator at the Department of English Studies, University of Cyprus. She is also the Coordinator of the Testing, Teaching and Translation Lab. Her area of expertise is applied linguistics, syntax, semantics and pragmatics, phonetics and phonology, speech perception and production, orthography, first and second language acquisition, bilingualism, multilingualism, sociolinguistics, teaching and education.

\section{Contact information:}

University of Cyprus, Department of English Studies

75 Kallipoleos, P.O. Box 20537, 1678 Nicosia, Cyprus

e-mail: karpava.sviatlana@ucy.ac.cy

ORCID: 0000-0001-8416-1431 
Natalia RINGBLOM $(\mathrm{PhD})$ is a Slavist affiliated with the Department of Slavic and Baltic studies, Finnish, Dutch and German at Stockholm University. She is also an educational developer at Dalarna University. Her main research interests include bilingualism, heritage language acquisition and maintenance, with a particular focus on Russian in Sweden. Natalia is a member of a COST Project: "Enhancing children's oral skills across Europe and beyond".

\section{Contact information:}

Universitetsvägen 10 E, Stockholm, 10691, Sweden

Dalarna University, Falun, 79188, Sweden

e-mail: natasha.ringblom@slav.su.se

ORCID: 0000-0002-1761-5971

Anastassia ZABRODSKAJA (PhD) is Professor of Intercultural Communication and Head of the Communication Management Master's programme at Tallinn University. She is in charge of the management of the European Master's in Intercultural Communication programme. Her primary research interests are identity, language contacts and linguistic landscape. She is a Regional Representative (Europe) on the Executive Committee of International Association of Language and Social Psychology and a Management Committee Member of the European Family Support Network COST Action: A bottom-up, evidence-based and multidisciplinary approach.

\section{Contact information:}

Tallinn University

Baltic Film, Media and Arts School

Narva mnt 27, 10120 Tallinn, Estonia

e-mail: anastassia.zabrodskaja@gmail.com

ORCID: 0000-0001-8082-3549

\section{Сведения об авторах:}

Светлана КАРПОВА - преподаватель прикладной лингвистики и координатор секции лингвистики на факультете изучения английского языка Университета Кипра. Она также является координатором лаборатории тестирования, обучения и перевода. Специализируется в области прикладной лингвистики, синтаксиса, семантики и прагматики, фонетики и фонологии, восприятия и воспроизведения речи, орфографии, овладения первым и вторым языком, двуязычия, многоязычия, социолингвистики, преподавания и обучения.

\section{Контактная информация:}

University of Cyprus, Department of English Studies

75 Kallipoleos, P.O. Box 20537, 1678 Nicosia, Cyprus

e-mail: karpava.sviatlana@ucy.ac.cy

ORCID: 0000-0001-8416-1431

Наталия РИНГБЛОМ $(\mathrm{PhD})$ - славист, преподает на кафедре славянских и балтийских языков, финского и немецкого языков Стокгольмского университета. Является разработчиком программ высшего образования в Университете Даларны. Сфера ее научных интересов включает билингвизм, изучение и сохранение эритажного языка, в особенности русского языка в Швеции. Она является членом Европейского COST проекта «Развитие устной речи детей в Европе и за ее пределами». 


\section{Контактная информация:}

Universitetsvägen 10 E, Stockholm, 10691, Sweden

Dalarna University, Falun, 79188, Sweden

e-mail: natasha.ringblom@slav.su.se

ORCID: 0000-0002-1761-5971

Анастасия ЗАБРОДСКАЯ (PhD) - профессор межкультурной коммуникации Таллинского университета и руководитель магистерской программы «Управление коммуникацией». Она также руководит программой «Европейские магистры по межкультурной коммуникации». Сферу ее научных интересов составляют идентичность, языковые контакты и языковой ландшафт. Она является региональным представителем Европы в Исполнительном комитете Международной ассоциации языков и социальной психологии и членом Межправительственной структуры по координации национальных исследований на европейском уровне по вопросам многоязычной семьи.

\section{Контактная информация:}

Tallinn University

Baltic Film, Media and Arts School

Narva mnt 27, 10120 Tallinn, Estonia

e-mail: anastassia.zabrodskaja@gmail.com

ORCID: 0000-0001-8082-3549 